\title{
Arthrospira platensis Mediated Biosynthesis of Silver Nanoparticles as Breast Cancer Proliferation and Differentiation Controlling agent: In-vitro and In- vivo Safety Approach
}

Nehal El Deeb ( $\square$ nehalmohammed83@gmail.com )

Genetic engineering and biotechnology research institute

\section{Mai Abo-Eleneen}

Tanta University Faculty of Science

\section{Omyma Awad}

Tanta University Faculty of Science

Atef Aboshady

Tanta University Faculty of Science

\section{Nano Express}

Keywords: Green synthesis, AgNPs, Anti-proliferative, Anticancer, Breast cancer

Posted Date: April 5th, 2021

DOI: https://doi.org/10.21203/rs.3.rs-382873/v1

License: (c) (1) This work is licensed under a Creative Commons Attribution 4.0 International License.

Read Full License 


\section{Abstract}

Biogenic Silver nanoparticles (AgNPs) are one of the most fascinating nanomaterials used in biomedical purposes. In the current study, we biosynthesized AgNPs using Arthrospira platensis, Microcystis aeruginosa and Chlorella vulgarisactive metabolites and evaluate their efficacy against breast cancer. The recovered AgNPs was characterized using scanning and transmission electron microscopy (SEM and TEM). The safety usage of bio-AgNPs was tested in-vitro on PBMCs cells and in-vivo. The obtained results indicated the safety usage of bio-AgNPs at concentration $0.1 \mathrm{mg} / \mathrm{ml}$ on PBMCs cells and $1.5 \mathrm{mg} / \mathrm{ml}$ on the tested Albino mice. The bio-AgNPs displayed dose-dependent cytotoxicity $(0.1 \mathrm{mg} / \mathrm{ml})$ against HepG-2, CaCO-2 and MCF-7 cell lines via ROS induction and arresting treated cells in G0/G1 and sub G0 phases. In addition, Arthrospira bio-AgNPs treatment induced cellular apoptosis in breast cancer cells via the down regulation of survivin, MMP7, TGF and Bcl2 genes expressions. Upon Arthrospira bioAgNPs treatment, a great delay in tumor growth and prolonged survival were recorded in breast cancer mice model. Furthermore, after Arthrospira bio-AgNPs treatment, a great reduction in Ki 67 protein marker from $60 \%$ to be $20 \%$ and was recorded and an elevation in Caspase 3 protein levels was recorded in treated groups with percentage $65 \%$ comparing with $45 \%$ in Doxorubicin treated groups.

\section{Introduction}

Cancer is a life-threatening disease and leads the cases of deaths around the world. According to the WHO, the annual cancer cases are to rise from 14 million in 2012 to 22 million in the next two decades (1).Thus, searching for potent effective and safe anticancer drugs is one of the most influenced objectives (2). Among the various approaches, the exploitation of nanotechnology is one of the most effective approaches to recognize different hits and leads (3). In nanomedicine field, there are great interest in the synthesis of metal nanoparticles as gold and silver to be as anticancer agents. $(4,5)$. Because of their distinct characters and promising applications in the medical fields as anticancer and antimicrobial, silver nanoparticles AgNPs are widely used. (6). There are three methods used in the preparation of nanoparticles; physical, chemical and biological synthesis(7). Green synthesis method is ultimately superior because of a multitude of reasons to begin with saving highly expensive chemicals and energy another reason is that the produced nanoparticles are preferred more than the nanoparticles manufactured with both chemical and physical methods finally this green method is eco-friendly (8). Plants, bacteria, fungi, algae, etc. are widely used in nanoparticles green synthesis $(9,10)$. In their extracts, various bioactive compounds found, as proteins/enzymes, amino acids, polysaccharides, polyphenols, aldehydes and ketones that acting as ions reducing and stabilizing agents during the nanoparticles production process to form the favorite shapes and sizes $(6,11)$. Among the microorganisms, microalgae have a wonderful part in nanoparticles preparation and metals toxicity bioremediation and their biotransformation to altered nontoxic materials $(12,13)$. Unlike the most reported microorganisms that used in AgNPs biosynthesis, blue green algae (Cyanobacteria) were used as nonpathogenic microorganisms that used in its biosynthesis, Spirulina platensis, is an important example of these microorganisms. Arthrospira (Spirulina) is filamentous cyanobacterium (Oscillatoriaceae) and 
shows great plasticity because it has a soft cell wall made of complex sugars and protein (14), they occur naturally in tropical and subtropical lakes at high $\mathrm{pH}$ and high carbonate and bicarbonate concentrations. In present study, we test the ability of $S$. platensis cell-free supernatant to form AgNPs in an aqueous system and investigate their anticancer effects against breast cancer. Moreover, we obtained preliminary visions on the molecular anticancer mechanisms against breast cancer using in-vitro and in-vivo breast cancer model.

\section{Results}

\section{Green Synthesis and characterization of silver nanoparticles}

\section{- Culturing and growth curves of vulgaris, A. platensis and M. aeruginosa}

The algal species growth was measured as optical density (O.D) every two days to determine the maximum growth of each different organism for collection. The obtained data indicated that $A$. platensis and $M$. aeruginosa optimum growth conditions were recorded upon culturing the algal species for 16 days on modified Zarrouk medium and BG11 at $27 \pm 2^{\circ} \mathrm{C}$ and 2500 LUX, respectively (Fig S1, a and C). While $C$.vulgaris maximum growth was recorded after culturing on Kuhl's medium for 18 days at $25 \pm 2{ }^{\circ} \mathrm{C}$ and 4000 LUX (Supplementary Fig S1b).

\section{- Green Synthesis and characterization}

Silver nanoparticles (AgNPs) in different sizes were biosynthesized using cell free supernatants of C.vulgaris, $A$. platensis and $M$. aeruginosa that collected at the algal growth phase maximum point; 10 , 12 and 16 days for $A$. platensis, M. aeruginosa and C.vulgaris, respectively (S1b). After 1 hour incubation time at $25^{\circ} \mathrm{C}$, all biologically active compounds of algal filtrates acted as reducing agents for silver ion. The primary analysis was done via solution color changes visual observation from colorless to brown reported AgNPs formation comparing with the negative control (silver nitrate aqueous solution) that remained colorless. Furthermore, both Scanning (SEM) and transmission (TEM) electron microscope analysis proved that, the recovered AgNPs were spherical shaped and formed with size range of $9-17 \mathrm{~nm}$ (Fig 1,2.)

\section{In-vitro safety assay and anticancer effects of bio-AgNPs}

\section{- Safety patterns of bio-AgNPs}

The safety usage of the bio-AgNPs was tested on normal mammalian cells; Human peripheral blood mononuclear cells (PBMC) using AgNPs serial dilutions from 0.125 to $4 \mathrm{mg} / \mathrm{ml}$ of bio-AgNPs concentrations. After treatment, cellular viability was quantified using MTs assay (Fig S2). The acquired results revealed that, the nontoxic doses of bio-AgNPs of M. aeruginosa, C.vulgaris and that $A$. platensis filtrates on PBMC cells was $0.1 \mathrm{mg} / \mathrm{ml}$ with cellular viability inhibition pepercentages:0.3,14.2 and 16.9, 
respectively. So, the concentration of $0.1 \mathrm{mg} / \mathrm{ml}$ of bio-AgNPs was selected to complete the in-vitro studies.

\section{Anticancer activities of the bio-AgNPs on HepG2, CaCO-2 and MCF-7 cancer cells}

The in-vitro assay of bio-AgNPs anticancer effects were done against 3 different cell lines using MTS assy. In general, the bio-AgNPs of all algal filtrates showed great abelites to inhibit cellular proliferations of the used cancer cell lines with inhibition percentages exceeded 95\%. Upon using the non-toxic bioAgNPs dose $(0.1 \mathrm{mg} / \mathrm{ml})$, the bio-AgNPs that synthesized with that $A$. platensis filtrates was the most potent treatment against HepG-2, CaCO-2 and MCF-7 cells with growth inhibition percentages of 86.2, 94.2 and 96.6, respectively (Fig.3, a, b, c). In addition, the calculated IC50 values of bio-AgNPs that synthesized with that $A$. platensis filtrates were $7.8,14.2$ and $5.9 \mu \mathrm{g} / \mathrm{ml}$ against HepG-2, CaCO-2 and MCF-7 cells, respectively (Fig. S3a). Furthermore, bio-AgNPs that synthesized with that $A$. platensis filtrates was the most potent treatment against MCF-7 cells with selectivity index exceed 1847 followed by the same treatment on HepG-2 cells with 1406.44 selectivity index value. Also, Microcystis-bio-AgNPs showed great toxic effects against CaCO-2 cells with 860.93 selectivity index value (Fig. S3 b). The morphological characters of MCF-7 treated cells with Arthrospira-bio-AgNPs were examined under the phase contrast microscope (Fig. S4). The photos showed the appearance of undergoing apoptotic cells that characterized by cellular rounding up, shrinkage, membrane blebbing and loss of cell adhesion.

\section{The mode of anticancer action of the bio- AgNPs}

\section{- Induction of cellular ROS by bio-AgNPs}

The intracellular reactive oxygen species were induced in PBMC using LPS as a positive control group and using bio-AgNPs of Microcystis, Chlorella and Arthrospira. The maximum induced ROS percentage (Fig. 4) was recorded upon PBMCs treatment with bio-AgNPs of Microcystis (50.16) followed by bioAgNPs of Arthrospira and Chlorella (46.3 and 40, respectively). The all used bio-AgNPs significantly induce higher percentages of ROS than both negative control cells (16.35) and positively LPS induced cells (19.51).

\section{- Flowcytometric cell cycle analysis after AgNPs treatment}

The cell cycle pattern of cancer cells (HepG-2, Caco2 and MCF7) after the treatment with Arthrospira-bioAgNPs were made by comparing the cellular pattern of treated cells with those of the untreated cells. After HepG-2 treatment with Arthrospira-bio-AgNPs, the gated cells population in sub G0 phase were increased by about $1.3 \%$ over the untreated cells percentage to record $35.6 \%$, where subG0 phase represent the apoptotic cells (Fig S4 a). While, upon CaCO-2 cells treatment, the treatment causing cells to be arrested in S phase by ratio $66.4 \%$ (Fig S5 b). On the other hand, the Arthrospira-bio-AgNPs treatment arrested MCF-7 cell in G0/G1 phase with gating percentage 61.6 (Fig S5 c).

\section{- Gene expression patterns of bio-AgNPs treated cancer cells}


The possible mechanisms of AgNPs-mediated cell death via the apoptotic regulators have been confirmed via gene expression analysis. In order to check the apoptotic pathway patterns, the gene expression levels of Bcl2, Survivin, MMP7, P53 and TGF were quantitatively measured by RT-PCR after $\beta$ actin normalization (Fig.5). The overall results indicated that, comparing with the untreated cells, Arthrospira bio-AgNPs treatment induced cellular apoptosis in breast cancer cells via the down regulation of survivin, MMP7, TGF and Bcl2 genes expressions. While Chlorella bio-AgNPs induced MCF-7 cellular apoptosis via MMP7 gene downregulation and P54 gene upregulation. Furthermore, upon MCF-7 cells treatment with Microcystis bio-AgNPs, cell apoptosis induction could be proved via survivin and MMP7 genes downregulation (Fig.5).

\section{- Induction of Apoptosis and necrosis}

The all above results indicated that Arthrospira-bio-AgNPs was the most potent treatment against all cell lines, and MCF-7 cells were the most sensitive one. So, the all-upcoming experiment will evaluate the efficacy of Arthrospira-bio-AgNPs against breast cancer models.

Nnuclear changes during apoptosis were visualized via fluorescence microscope using acridine orange/ethidium bromide (AO/EB) staining. In the living cells, nuclei appeared with normal green staining with green chromatin and they showed organized structures, while in the early apoptotic stage, cells exhibited condensed or fragmented chromatin (green or orange). Nevertheless, during late apoptotic or necrotic stages, cells have displayed similar normal nuclei staining, as live cells, but with orange chromatin. Upon MCF-7 cellular treatment with Arthrospira-bio-AgNPs, the treated cells appeared with an early apoptotic feature with orange-stained multinucleated cells (Fig. 6).

\section{In-vivo safety assay and anticancer effects of Arthrospira bio-AgNPs}

\section{- In-Vivo safety assay}

Upon our previous results, the safety usage of Arthrospira bio-AgNPs was tested on albino mice using two doses ( 3 and $1.5 \mathrm{mg} / \mathrm{ml}$ ). The results indicated that, the first treated group with $3 \mathrm{mg} / \mathrm{ml}$ of bioAgNPs showed significant elevation in the serum concentrations of ALT, AST and ALP from the control group. While the group that received $1.5 \mathrm{mg} / \mathrm{ml}$ of bio-AgNPs didn't record significant differences from control group. Also, the animal group that treated with $1.5 \mathrm{mg} / \mathrm{ml}$ of bio-AgNP didn't showed any significant differences with the control group in the concentration of serum protein, albumin and creatinine and with slightly elevation in the concentrations of serum urea and bilirubin (Fig S6).

\section{- Antitumor effect of the Arthrospira bio-AgNPs on mouse tumor model}

To confirm the antitumor effects of Arthrospira bio-AgNPs, AgNPs were injected into BALB/C mice via two routs; I.P and SC. Injection and compared with doxorubicin treated group which intraperitoneally injected with $0.15 \mathrm{mg} / \mathrm{ml}$ and $3.5 \mathrm{gm} / \mathrm{Kg}$ body weight (Fig 7a). The tested mice body weight results during 30 days of the experiment showed dramatically weight loss of all animals over the first days of tumor 
(Fig. 7 b). Also, the tumor size increased intensively over the first days of the experiment then, the growth started to be inhibited obviously after all treatment regimen (Fig. $7 \mathrm{c}$ ). The all used treatment are able to induce a great delay in tumor growth and prolonged survival in mice without significant differences among them. Also, the results of red blood cells (RBCs), White blood cells (WBCs) and platelets counts were recorded in all animal groups (Fig. 7 D). Comparing with the control group, the DOX group mice showed the lowest count of all blood parameters; $5.7 \times 10^{3}$ cells $/ \mu \mathrm{L}$ for RBCs, $3.46 \times 10^{3}$ cells $/ \mu \mathrm{L}$ of WBCs and platelet count reached $1.1 \times 10^{3}$ cells $/ \mu \mathrm{L}$ platelets. While the highest inhibition values were recorded in the group that treated intratumorally with Arthrospira bio-AgNPs followed by that injected intraperitonially. The mice in all groups were observed for distress marks (weight loss; dehydration; rapid or shallow breathing; hunched posture/immobility; piloerection; guarding behavior; bleeding from any orifice; death). All mice in the AgNPs groups tolerated the used dose with no apparent toxicity.

\section{- Histopathological analysis of breast tumors}

Next, to confirm the above outcomes in the in-vivo setting, mice bearing Ehrlich Ascites Carcinoma cells were treated three times with bio-AgNPs of Arthrospira, DOX and PBS. All groups were monitored for tumor progression and survival. The histopathological examination results of the DOX., PBS and AgNP treated mice groups indicated the presence of viable tumor and necrotic areas in all samples with a smaller number of malignant, advanced necrotic and fibrotic cells (Fig. 8 a). The tissue sections of the control group indicated malignant cells, increased N/C ratio, loss of cell architecture and necrosis and metastasis in lipid layer (Fig. 8 a). While in the animal groups which treated with DOX., the breast tissue section showed fibrotic reactions, advanced necrosis, less malignant viable cells (Fig. 8 a).

\section{- Immunohistochemistry (IHC) staining of tumor tissue}

Immunohistochemistry allows the evaluation of proteins cellular localization in the context of tumor structure. Ki67 is a nuclear antigen present in mid G1, S, G2, and the entire M phase of the cell cycle, it serves as a proliferation marker. Our immunohistochemistry results of Ki 67 marker in the induced breast tumors mice (appeared as brown color spots) reach $60 \%$ in the untreated mice sections. This percentage was highly reduced to be $20 \%$ in the tumor sections of mice treated with Arthrospira bio-AgNPs (injected in solid tumors). While, in the Doxorubicin treated group, Ki 67 protein levels in breast tumors of mice which treated with Arthrospira bio-AgNPs (I.P injected) was less than it (8\%, Fig.8 b). on the other hand, the activated caspase-3 and caspase- 7 can cleave multiple structural and regulatory proteins, which are critical for cell survival and maintenance. On contrary with the previous results, Caspase 3 protein (the apoptotic biomarker) in the tumor sections of untreated mice was almost absent while it was existed with about $25 \%$ in the tumor sections of mice that treated with Arthrospira bio-AgNPs (injected in solid tumors). The highest levels of Caspase 3 protein were observed in the tumor groups that intraretinally treated with Arthrospira bio-AgNPs with percentage $65 \%$ comparing with $45 \%$ in Doxorubicin treated groups (Fig.8 C).

\section{- Ethical statement.}

Loading [MathJax]/jax/output/CommonHTML/fonts/TeX/fontdata.js

Page 6/25 
All in-vivo studies were done according to City of Scientific Research and Technological Applications, Egypt guidelines. The Research Ethical Committee at the pharmaceutical industries center, Egypt under international and institutional guidelines (REC-FPTU) approved all used experimental protocols.

\section{Discussion}

Breast cancer is a major ongoing public health matter among women in both developing and developed countries. In the past decades, there were strong improvement in the development of breast cancer treatment. Nevertheless, the existing clinical lines are invasive with low specificity and lead to sever side effects. The rapid development of nanotechnology in medical fields strongly supported human cancer diagnosis and treatment fields. Nanoparticles-based strategies could overcome the cellular barriers and permits sustained blood circulation period, more tumor targeting and improved the drugs-tumors accumulation $(15,16)$. There are various nanomedicines that approved by the US FDA or under different stages of development in clinical trials as breast cancer therapeutics as; Abraxane, Nanoparticle albuminbound paclitaxel, that approved in $2005(17,18)$ or non-approved yet as tamoxifen/AgNPs dual corefolate decorated shell (4). In the nanomedical field, the selected biomaterials should be systemically nontoxic and biocompatible (19) to be approved in cancer treatment. So, we focused on the green synthesis of non-toxic and biocompatible AgNPs using microalgal extracts with size ranged from 9-17nm with anti-cancer properties. Various studies indicated the successfulness role of different cyanobacterial filtrates in the biosynthesis of AgNPs(20-23). Mahdieh et al. (24) explained that, iron nanoparticles formation is due to ion reduction to metal nanoparticles by algal extracellular reductase that secreted in the cell free supernatant. In addition to the algal extracellular reductase, Hamouda et al. (20) clarified the role of algal extracellular proteins of Oscillatoria Willei NTDM01 as a capping agent in the formation of spherical AgNPs (100-200 nm). The algal extracellular proteins or polysaccharides could bind to the nanoparticles either through free amine groups or $(25)$ cysteine residues $(26,27)$. In addition to the synthesis of suitable anticancer, the safety usage and the limit adverse effects of any newly tested drugs in parallel with drug efficacy are the main important issues in the success of their approval as therapeutic agents. So that, our safety usage assessment of the bio-AgNPs were confirmed at both in-vitro and invivo levels. Our results indicated that, on PBMC cells, the nontoxic doses of bio-AgNPs that synthesized by Microcystisaeruginosa, Chlorellavulgaris and Arthrospiraplatensis filtrates were $0.1 \mathrm{mg} / \mathrm{ml}$ which showed cellular viability inhibition percentages $10.3,14.2$ and 16.9 , respectively. While another study by Yang et al. (28) tested the cytotoxic effects of AgNPs with different sizes ( $5 \mathrm{~nm}, 28 \mathrm{~nm}$ and $100 \mathrm{~nm}$ ) on PBMCs, they indicated that, the nontoxic doses of AgNPs ranged 0.15 to $0.3 \mu \mathrm{g} / \mathrm{ml}$ which is very closed to our finding. Furthermore, other studies investigated the cytotoxic effects of the biogenic 0-AgNPs on human erythrocytes integrity(20). Hamouda et al. (20)clarified that, by using AgNPs at concentrations, $0.5,5.0,7.5,10 \mu \mathrm{g} / \mathrm{ml}$ showed cell lysis as $0.45,0.76,1.03,1.68 \%$, respectively on blood cell culture. The cellular toxicity mode of actions of AgNP were mainly based on their physico-chemical characters as shape, charges, sizes, stabilization and presence of other capping molecules with the type of the targeted cells so that, the nanoparticles toxicity must be checked on different cell types (29-32). In context, the cannina nronoce of $\triangle a N D c$ with nortain nolvmare ar nolveaccharides at definite concentrations showed a Loading [MathJax]/jax/output/CommonHTML/fonts/TeX/fontdata.js 
promising biological activity without any cytotoxic effects with that effective dose (33), these findings could explained the safety usage of our prepared bio-AgNPs. At the in-vivo level, spleen, liver and kidney are the most affected organs to AgNPs toxicity (their negative effects include ROS induction, pathological changes in liver morphology, and enzyme activity) with less distribution profile in the other organs(34, 35). However, our previous data (supplementary file) showed that, the intraperitoneal injection of Arthrospira bio-AgNPs at $1.5 \mathrm{mg} / \mathrm{Kg}$ into Albino mice didn't record any significantly effects on the liver or kidney functions. Again, this non cytotoxic effects could be explained by a study of Ashraf et al. (36), they explained that AgNPs green synthesis approach provide advanced direction for NPs synthesis without using toxic reductants and stabilizers, which mean more safety and less cytotoxic effects. Concerning with the anticancer efficacy of AgNPs, many recent studies reported the anticancer effects of AgNPs against different cancer cell lines as breast $(4,37)$, ovary $(38)$, brain $(39,40)$, cervix (41), liver(42), colon(16, 43), lung(44), pancreas(45), and blood(46-48). At the in-vitro level, Swanner et al., (37)reported that, the non-toxic doses of AgNPs (tested on the non-cancerous cell lines and normal cells; Kidney, liver and monocytes) were toxic to 3 different triple negative breast cancer cell lines. In this context, our obtained results proved the anticancer effects of Arthrospira-bio-AgNPs against HepG-2, CaCO-2 and MCF-7 cells with inhibition percentages 86.2, 94.2 and 96.6, respectively. Furthermore, this treatment showed 1847.05 selectivity index against MCF-7 cells. In order to explain the exact mode of action of AgNPs against cancer cells, many recent reports tried to explain this action, Swanner et al.,(37) explained that, MDA-MB-231 breast cancer cells treated with AgNPs at dose $37.5 \mu \mathrm{g} / \mathrm{mL}$ reduce cell number in G0/G1 phase with an increase and cell cycle arrest in S-phase cells. In the same context, our obtained results indicated that after AgNPs treatment, the treated CaCO-2 cell arrested in S phase and MCF-7 cell cycle arrested in G0/G1 phase with cells population increasing in subG0 phase. Furthermore, recent research was explained another key role in the AgNPs anticancer effects against different cancer cell this factor is the cellular redox balance and ROS $(4,49)$. Our quantified ROS results indicated a significant induction in the intracellular ROS using all tested bio-AgNPs comparing with both positive (LPS induced) and negative PBMCs control cells. In addition to ROS induction and the alteration in cell cycle pattern, our results indicated that, the tested bio-AgNPs cytotoxic effects against breast cancer cells could be explained via MMP7, TGF and Bcl2 genes downregulation. There are few reports that tried to clarify the role of AgNPs as a regulatory agent in cancer cell apoptotic or proliferative pathways. Our previous work(16) clarified that, the biogenic AgNPs that synthesized by Balanites aegyptiaca saponins showed anticancer effects in-vitro against colon and liver cancer cells by the downregulation of MMP7, BCL2 and upregulation of IKaB. The mode of action of AgNPs embedded with Arthrospira extracts to inhibit MFC-7 proliferation was explained through $\mathrm{BCl} 2$-caspase cascade that mediated mitochondrial dysfunction complemented with TGF-b/MMp7 pathway(50). These pathway combinations may be the cause of cytoxic effects of AgNPs against MCF7 even at lower concentration that explained by our mentioned results. For more explanation to the Arthrospira-bio-AgNPs mode of action at the in-vivo level, the immuno-histochemistry analysis of tumor bearing mice indicated that caspase 3 levels of control and treated mice were comparable with stanning intensity varied from strong to weak. Caspase 3 is considered as the most important part of cellular apoptotic pathway; caspase 3 active form levels has 
used as patient's overall survival prognostic marker (51). The current study indicated the potentialities of AgNPs to induce cell death through caspase-dependent pathways activation, that recorded from an elevation in caspase3 level in the treated group. The activated caspase that recorded in Arthrospira-bioAgNPs treated groups could be resulted from the initiation of silver ions from AgNPs that induce oxidative stress that in turns activate caspase 3 (52). The same findings were recorded by Urbańska et al. (53), they indicated that caspase 3 levels in AgNPs treated glioblastoma multiform in-vivo model looked to be on the border between the spontaneous and the induced apoptosis. Interestingly, our current results showed that Arthrospira-bio-AgNPs treatment was highly reduced Ki-67 percentage from $60 \%$ to $20 \%$ in the mice tumor sections. Ki-67, proliferation marker, is the most controversially used parameter in breast cancer treatment and diagnosis(54). Ki-67 antigen is expressed in S, G1, G2 and M cell cycle phase (55) that mean upon treatment, the Ki-67 antigen reduction could arrest cell cycle in the one of the abovementioned phases. This finding supported our previously mentioned results that MCF-7 cell cycle arrest in G1 phase upon Arthrospira-bio-AgNP treatment which resulted in Ki-67 antigen reduction in the tested tissues. The all above explained factors could be illuminated the mode of anticancer actions of BioAgNPs against breast cancer.

\section{Conclusion}

Finally, we concluded that, Algal-mediated synthesis of silver nanoparticles using the extract of Arthrospira platensis promotes green nanotechnology. The current study showed the cytotoxic effects of Arthrospira-bio-AgNP against breast cancers at both in-vitro and in-vivo compared to the standard doxorubicin. The Arthrospira-bio-AgNP treatment at the nontoxic doses provides a novel alternate or complementary approach in breast cancer treatment.

\section{Discussion}

\section{Green synthesis and characterization of silver nanoparticles (AgNPs) using algal free culture}

\section{- Microorganism strains and culture conditions}

Chlorella vulgaris was cultured on Kuhl's medium for 20 days at $25 \pm 2^{\circ} \mathrm{C}$ and 200 LUX shacked twice per day also, Arthrospira platensis (accession number MW396472) was cultured on modified Zarrouk medium for 16 days at about $27 \pm 2^{\circ} \mathrm{C}$ and 2500 LUX shacked twice per day while Microcystisaeruginosa was cultured on BG11 for 16 days at about $27 \pm 2^{\circ} \mathrm{C}$ and 2500 LUX shacked twice per day.

\section{- Green synthesis of AgNPs}

Fifty $\mathrm{ml}$ of AgNO3 $(1 \mathrm{Mm})$ were added drop wisely to one $\mathrm{ml}$ of each culture filtrate of $A$. platensis $(\mathrm{PH}=$ 11), M.aeruginosa $(\mathrm{PH}=6)$ and $C$. vulgaris $(\mathrm{PH}=6.6)$. Each preparation was shacked for 1 hour $(220 \mathrm{rpm})$ at room temperature, then was centrifuged at $10000 \mathrm{rpm}$ for $10 \mathrm{~min}$., the formed pellets were washed 3 times with distilled water before lyophilization and storing in room temp. till use. 


\section{- Characterization of the synthesized bio-AgNPs}

\section{Scanning electron microscopy}

The morphology of bio-AgNPs was analyzed using scanning electron microscopy at an accelerated voltage of $15 \mathrm{kV}$. The samples surfaces were vacuum coated with gold for SEM and with the aid of X-ray diffraction. The microstructures of the biogenic AgNPs particles were observed by using a Joel 6360LA scanning electron microscope (JEOL Ltd., Tokyo, Japan). Silver samples were mounted on the specimen holder with double sided adhesive tape. After gold coating using a JFC-1100E sputter (JOEL Ltd., Tokyo, Japan), the images were captured using an accelerating voltage of $15 \mathrm{kV}$.

\section{- Transmission electron microscopy (TEM).}

The collected bio-AgNPs pellets were dispersed in distilled water. The Bio-AgNPs microstructures were studied with a Joel 6360LA transmission electron microscope (JEOL Ltd., Tokyo, Japan), by double sided adhesive tape. A thin film of sample was prepared by placed $5 \mu$ of the collected AgNPs on a carbon coated 3-mm copper grid and dried at room temperature. Image J software was used for examination and poly dispersity index was calculated according to the following equation:

\section{Poly Dispersity Index $(\mathrm{PDI})=\left(\frac{\text { Standard Deviation }}{\text { Mean Diameter }}\right)^{2}$}

\section{In-vitro safety assay and anticancer effects of bio-AgNPs}

- Safety assay of bio-AgNPs on Peripheral Blood Mononuclear Cells (PBMC)

For the determination of the bio-AgNPs non-toxic dose that does not display a toxic force on PBMC cells, the cytotoxic assay was accomplished using MTS assay. A cell suspension of $6 \times 10^{4} \mathrm{cell} / \mathrm{ml}$ was seeded $\left(100 \mu \mathrm{l}\right.$ cell suspension per well) in 96 -well plates. The plates were incubated at $37^{\circ} \mathrm{C}$ in humidified $5 \%$ $\mathrm{CO}_{2}$ for $24 \mathrm{hr}$. After that, the exhausted old medium was discarded and replaced by either $100 \mu \mathrm{l}$ of different treatment concentrations (prepared in culture medium) or medium (as a negative control) were added. The cell plates were incubated at the same growth conditions for 3 days. After 3 days, the cytotoxic effects were quantified using MTS assay Kit according to the instruction protocol.

\section{- In-vitro anticancer activity of green synthesized AgNPs on HepG-2, CaCO-2 and MCF-7 cell lines}

The anticancer activities of the Chlorella bio-AgNPs, Microcystis bio-AgNPs and Arthrospira bio-AgNPs on HepG-2, CaCO-2 and MCF-7 cell lines were quantified using MTS assay as described above.

\section{- Selectivity index}


The selectivity index of the recovered bio-AgNPs to cancer cells was quantified according to Koch et al. (56) protocol with a minor modification, where; SI=IC50nc /IC50cc, where IC50nc refers to the IC50 value of the tested compound on normal cells while; IC50cc refers to the IC50 of the tested compound on cancer cell line.

\section{The mode of anticancer action of the bio- AgNPs}

\section{- Intracellular reactive oxygen species induction after AgNPs treatment}

The total induced intracellular ROS by Chlorella, Microcystis and Arthrospira bio-AgNPs was detected in PBMC using 2, 7-dichloro dihydrofluorescein diacetate $\left(\mathrm{H}_{2}\right.$ DCF-DA) method. DFCH-DA enters cells and further oxidized by ROS forming fluorescent product 2',7'-dichlorofluorescein (DCF). Briefly, PBMC cells were grown in 96 well plates for $24 \mathrm{hrs}, 100 \mu \mathrm{l}$ of the non-toxic doses of AgNPs were added to cells and incubated for $24 \mathrm{hrs}$. After that, cells were incubated with $\mathrm{H}_{2}$ DCF-DA at a final concentration $50 \mu \mathrm{M}$ for 30 min. In the positive control group, ROS was induced by loaded cells with E. coli LPS (lipopolysaccharide $100 \mathrm{ng} / \mathrm{ml}$ ) in RPMI. After $1 \mathrm{~h}$ incubation, the stimulants were discarded and cells were washed three times with pre warmed PBS, all samples were analyzed using a BD FACSC a libur flow cytometer with Cell Quest software. For quantification of DCF fluorescence, at least 10,000 events were used for each measurement (5).

\section{- Cell cycle analysis by flowcytometry}

The alteration in the cell cycle patterns of HepG-2, CaCO-2 and MCF-7 cancer cells upon Arthrospira bioAgNPs treatments were determined using flow cytometry according to Léonce et al. (57) using PI as cellular stain discriminate living cells from dead cell. After treatment, cell suspensions were stained with $0.5 \mathrm{~mL}$ of warm PI solution ( $7 \mathrm{ml}$ of PI solution consists of $0.35 \mathrm{ml}$ of PI solution $(1 \mathrm{mg} / \mathrm{ml}), 0.7 \mathrm{ml}$ RNase A solution $(1 \mathrm{mg} / \mathrm{ml})$, and $6 \mathrm{ml}$ of PBS). The all samples were kept on ice until flow cytometric analysis.

\section{- Induction of Apoptosis and necrosis assessment}

Acridine orange and ethidium bromide (AO/EB) assay was used to differentiate between Apoptosis and necrosis cellular status.

Acridine orange could stain both live and dead cells while; ethidium bromide stain only cells that have lost membrane integrity. After Arthrospira bio-AgNPs treatment, MCF-7 cell suspension $\left(0.5 \times 10^{6}\right.$ cells/ml) was incubated with $1 \mu \mathrm{l}$ of AO/EB solution. Using a fluorescence microscope, $10 \mu \mathrm{l}$ of cell suspension was examined onto a microscopic slide (58).

\section{- The regulatory effects of AgNPs to oncogenes and tumor suppressor genes.}

The anticancer activity of the Arthrospira bio-AgNPs was explained by studying their effects in controlling 
Survivin genes in MCF7 treated cells. RNA was extracted using the Qiagen RNA Kit after 24 hrs treatment with sub-IC50 concentrations, and CDNA was synthesized using the Transcript or First Strand CDNA Synthesis Kit (Roche). Real-time qPCR was conducted using primer sets listed in Table (S1) and SYBR Green Master Mix (Applied Biosystems). The obtained results were analyzed using a CFX-96 (Bio-Rad) and the gene expression levels were calculated relative to $b$-actin and expressed as a fold change compared with control.

\section{In-vivo safety assay and anticancer effects of Arthrospira bio-AgNPs}

Based on the In-vitro studies, Arthrospira bio-AgNPs was selected to complete the all in-vivo experiments due to its efficacy and safety usage.

\section{- In-vivo safety}

Albino mice (35-45 gm) that used in this study were purchased from VACSERA, Cairo, Egypt. After an adaptation period of one week, the experimental animals were divided into three groups, each of $5 \mathrm{male}$ albino mice (35-45 gm).

All animal studies were approved Medical Research Institute, Alexandria, Egypt, Animal Care and Use Committee. In the first group, 5 males of mice were given intraperitoneal (27) injected with Arthrospira bio-AgNPs $(0.3 \mathrm{mg} / \mathrm{ml})$ in distilled water $(7 \mu \mathrm{g} / \mathrm{g}$ body weight). The second group mice; 5 mice were IP injected with $0.15 \mathrm{mg} / \mathrm{ml}$ bio-AgNPs in distilled water $(3.5 \mu \mathrm{g} / \mathrm{g}$ body weight). The last group represent the control untreated one that injected with $9 \%$ saline. Animal health was monitored daily, and mice were euthanized when moribund. After 2 weeks and upon sacrifice, serum samples were collected for different blood biochemical tests. The serum alanine aminotransferase (17), aspartate aminotransferase (27) and Alkaline phosphatase (ALP) activities and Serum total protein, Serum albumin concentration, Urea and Serum creatinine concentrations were determined using Bio diagnostic kit, Egypt according to its manual instruction.

\section{In-Vivo Tumor Model and Arthrospira bio-AgNPs treatment}

Mice were subcutaneously injected with 2 X105 of Ehrlich Ascites Carcinoma cells (Ehrlich cells, EAC) in the right flank of BALB/C. The mouse was monitored carefully, and the size of the tumor was measured by Vernier caliper. After 5 days from tumor induction, the tumors were measured for different treatment start. Mice were then grouped based on Vernier caliper measurements to ensure each treatment group started with the same average tumor burden. After tumor induction and calibration, the animals were divided into four groups, each of 5 female mice (22-28 gm).

After 7 days of tumor induction, In the first group, 5 females of tumor bearing mice were IP injected with $0.15 \mathrm{mg} / \mathrm{ml}$ AgNPs nanoparticles in distilled water (3.5gm/ $\mathrm{Kg}$ body weight). The second group, 5 females of tumor bearing mice were injected locally (intertumoral injections) with $0.15 \mathrm{mg} / \mathrm{ml}$ AgNPs in distilled water (3.5gm/ $\mathrm{Kg}$ body weight). In the positive control group, 5 females of tumor bearing mice were IP Loading [MathJax]/jax/output/CommonHTML/fonts/TeX/fontdata.js eight). Also, 5 females of tumor bearing mice 
were IP injected with 9\% saline as the negative control group. All mice bearing Ehrlich Ascites Carcinoma were treated 3 times at day 7,10 and 17. Tumor measurements were performed every 2 days and calculated as tumor volume $=$ (width $2 \times$ length) $/ 2$ as reported(59), and mice in all groups were observed for tumor growth and survival. Animals were followed until they reached kill criteria (until animals reached kill standards; tumor burden reached $10 \%$ of body weight, the presence of tumor ulceration or mice became dying).

The study lasted for 1 month before scarifying under diethyl ether anesthesia, serum samples, tumors tissue and different organs were collected for different blood biochemical and histopathological tests.

\section{- Histopathology and Immunohistochemistry studies}

After mice scarifying and organs collections, one longitudinal half of each organ was fixed at $10 \%$ formalin for the histopathological analysis. The obtained sections were stained with hematoxylin and eosin (H\&E), examined microscopically for presence of negative features, such as edema, erosion and necrosis compared with control and eventually photographed. For immunohistochemical examination, 3 $\mu \mathrm{m}$ samples section were deparaffinized with xylene and ethanol and the Intrinsic peroxidase activity in tissue sections was blocked with Peroxidase. After protein blockage, the sections were incubated with anti-Ki 67 and anti-Caspase 3 antibodies (60) for 30 minutes and then washed for 5 minutes two times in PBS. Mayer's hematoxylin was used to counterstain the slides. The immune stained sections were examined under a light microscope (Olympus BX53, Tokyo, Japan).

\section{- Statistical analysis}

Results are presented as mean \pm SD (standard deviation) for three replicates. The statistical analyses were carried out using SAS program. Data obtained were analyzed statistically to determine the degree of significance between treatments using one- and two-way analysis of variance (ANOVA) at P $\leq 0.005$ (SAS program 1989-1996). IC50 values and the statistical analysis of cytotoxicity and safety assays experiments were carried out using GraphPad prism 8.

\section{Declarations}

\section{Data availability statement}

All data generated or analyzed during this study are included in this published article (and its supplementary information files).

\section{Conflict of interest}

The authors declare that they have no conflict of interest.

\section{Funding information}


This research did not receive any specific grant from funding agencies in the public, commercial, or notfor-profit sectors.

\section{Author's contributions}

Nehal: designing of the work, the acquisition, analysis, interpretation of data, drafted the work and substantively revised.

Mai: Helped in the acquisition, analysis, interpretation of data, drafted the work.

Omyma and Atef: Supervised, revised and approved the submitted version.

\section{References}

1. McGuire S. World Cancer Report 2014. Geneva, Switzerland: World Health Organization, International Agency for Research on Cancer, WHO Press, 2015. Advances in Nutrition. 2016;7(2):418-9.

2. Al-Madboly LA, El-Deeb NM, Kabbash A, Nael MA, Kenawy AM, Ragab AE. Purification, Characterization, Identification, and Anticancer Activity of a Circular Bacteriocin From Enterococcus thailandicus. Front Bioeng Biotechnol. 2020;8:450.

3. Chenthamara D, Subramaniam S, Ramakrishnan SG, Krishnaswamy S, Essa MM, Lin F-H, et al. Therapeutic efficacy of nanoparticles and routes of administration. Biomaterials Research. 2019;23(1):20.

4. Ibrahim OM, El-Deeb NM, Abbas H, Elmasry SM, El-Aassar MR. Alginate based tamoxifen/metal dual core-folate decorated shell: Nanocomposite targeted therapy for breast cancer via ROS-driven NF-KB pathway modulation. Int J Biol Macromol. 2020;146:119-31.

5. Yassin AM, Elnouby M, El-Deeb NM, Hafez EE. Tungsten Oxide Nanoplates; the Novelty in Targeting Metalloproteinase-7 Gene in Both Cervix and Colon Cancer Cells. Appl Biochem Biotechnol. 2016;180(4):623-37.

6. Pugazhendhi A, Edison T, Karuppusamy I, Kathirvel B. Inorganic nanoparticles: A potential cancer therapy for human welfare. Int J Pharm. 2018;539(1-2):104-11.

7. Iravani S, Korbekandi H, Mirmohammadi SV, Zolfaghari B. Synthesis of silver nanoparticles: chemical, physical and biological methods. Res Pharm Sci. 2014;9(6):385-406.

8. Saratale RG, Karuppusamy I, Saratale GD, Pugazhendhi A, Kumar G, Park Y, et al. A comprehensive review on green nanomaterials using biological systems: Recent perception and their future applications. Colloids Surf B Biointerfaces. 2018;170:20-35.

9. Agarwal H, Venkat Kumar S, Rajeshkumar S. A review on green synthesis of zinc oxide nanoparticles - An eco-friendly approach. Resource-Efficient Technologies. 2017;3(4):406-13.

10. Elshinawy MI, Al-Madboly LA, Ghoneim WM, El-Deeb NM. Synergistic Effect of Newly Introduced Root Canal Medicaments; Ozonated Olive Oil and Chitosan Nanoparticles, Against Persistent Endodontic 
11. Rajan R, Chandran K, Harper SL, Yun S-I, Kalaichelvan PT. Plant extract synthesized silver nanoparticles: An ongoing source of novel biocompatible materials. Industrial Crops and Products. 2015;70:356-73.

12. El-Deeb NM, Abo-Eleneen MA, Al-Madboly LA, Sharaf MM, Othman SS, Ibrahim OM, et al. Biogenically Synthesized Polysaccharides-Capped Silver Nanoparticles: Immunomodulatory and Antibacterial Potentialities Against Resistant Pseudomonas aeruginosa. Front Bioeng Biotechnol. 2020;8:643.

13. Igiri BE, Okoduwa SIR, Idoko GO, Akabuogu EP, Adeyi AO, Ejiogu IK. Toxicity and Bioremediation of Heavy Metals Contaminated Ecosystem from Tannery Wastewater: A Review. J Toxicol. 2018;2018:2568038.

14. Fujisawa T, Narikawa R, Okamoto S, Ehira S, Yoshimura H, Suzuki I, et al. Genomic structure of an economically important cyanobacterium, Arthrospira (Spirulina) platensis NIES-39. DNA Res. 2010;17(2):85-103.

15. Tang X, Loc WS, Dong C, Matters GL, Butler PJ, Kester M, et al. The use of nanoparticulates to treat breast cancer. Nanomedicine (Lond). 2017;12(19):2367-88.

16. Yassin AM, El-Deeb NM, Metwaly AM, El Fawal GF, Radwan MM, Hafez EE. Induction of Apoptosis in Human Cancer Cells Through Extrinsic and Intrinsic Pathways by Balanites aegyptiaca Furostanol Saponins and Saponin-Coated SilverNanoparticles. Appl Biochem Biotechnol. 2017;182(4):1675-93.

17. El-Readi MZ, Althubiti MA. Cancer Nanomedicine: A New Era of Successful Targeted Therapy. Journal of Nanomaterials. 2019;2019:4927312.

18. Ventola CL. Progress in Nanomedicine: Approved and Investigational Nanodrugs. P t. 2017;42(12):742-55.

19. Rheder DT, Guilger M, Bilesky-José N, Germano-Costa T, Pasquoto-Stigliani T, Gallep TBB, et al. Synthesis of biogenic silver nanoparticles using Althaea officinalis as reducing agent: evaluation of toxicity and ecotoxicity. Sci Rep. 2018;8(1):12397.

20. Hamouda RA, Hussein MH, Abo-Elmagd RA, Bawazir SS. Synthesis and biological characterization of silver nanoparticles derived from the cyanobacterium Oscillatoria limnetica. Sci Rep. 2019;9(1):13071.

21. Husain S, Afreen S, Hemlata, Yasin D, Afzal B, Fatma T. Cyanobacteria as a bioreactor for synthesis of silver nanoparticles-an effect of different reaction conditions on the size of nanoparticles and their dye decolorization ability. Journal of Microbiological Methods. 2019;162:77-82.

22. Rosman NSR, Harun NA, Idris I, Ismail WIW. Eco-friendly silver nanoparticles (AgNPs) fabricated by green synthesis using the crude extract of marine polychaete, Marphysa moribidii: biosynthesis, characterisation, and antibacterial applications. Heliyon. 2020;6(11):e05462.

23. Tomer AK, Rahi T, Neelam DK, Dadheech PK. Cyanobacterial extract-mediated synthesis of silver nanoparticles and their application in ammonia sensing. International Microbiology. 2019;22(1):4958.

24. Mahdieh M, Zolanvari A, Azimee AS, Mahdieh M. Green biosynthesis of silver nanoparticles by 
25. Sharma A, Sharma S, Sharma K, Chetri SPK, Vashishtha A, Singh P, et al. Algae as crucial organisms in advancing nanotechnology: a systematic review. Journal of Applied Phycology. 2016;28(3):175974.

26. Othman AM, Elsayed MA, Al-Balakocy NG, Hassan MM, Elshafei AM. Biosynthesis and characterization of silver nanoparticles induced by fungal proteins and its application in different biological activities. J Genet Eng Biotechnol. 2019;17(1):8-.

27. Skandalis N, Dimopoulou A, Georgopoulou A, Gallios N, Papadopoulos D, Tsipas D, et al. The Effect of Silver Nanoparticles Size, Produced Using Plant Extract from Arbutus unedo, on Their Antibacterial Efficacy. Nanomaterials (Basel). 2017;7(7):178.

28. Yang EJ, Kim S, Kim JS, Choi IH. Inflammasome formation and IL-1 $\beta$ release by human blood monocytes in response to silver nanoparticles. Biomaterials. 2012;33(28):6858-67.

29. Carnovale C, Bryant G, Shukla R, Bansal V. Identifying Trends in Gold Nanoparticle Toxicity and Uptake: Size, Shape, Capping Ligand, and Biological Corona. ACS Omega. 2019;4(1):242-56.

30. Fratoddi I, Venditti I, Cametti C, Russo MV. How toxic are gold nanoparticles? The state-of-the-art. Nano Research. 2015;8(6):1771-99.

31. Gerber A, Bundschuh M, Klingelhofer D, Groneberg DA. Gold nanoparticles: recent aspects for human toxicology. Journal of Occupational Medicine and Toxicology. 2013;8(1):32.

32. Hornos Carneiro MF, Barbosa F. Gold nanoparticles: A critical review of therapeutic applications and toxicological aspects. Journal of Toxicology and Environmental Health, Part B. 2016;19(3-4):129-48.

33. Liu J, Zhao Y, Guo Q, Wang Z, Wang H, Yang Y, et al. TAT-modified nanosilver for combating multidrug-resistant cancer. Biomaterials. 2012;33(26):6155-61.

34. Ferdous Z, Nemmar A. Health Impact of Silver Nanoparticles: A Review of the Biodistribution and Toxicity Following Various Routes of Exposure. Int J Mol Sci. 2020;21(7).

35. Patlolla AK, Hackett D, Tchounwou PB. Silver nanoparticle-induced oxidative stress-dependent toxicity in Sprague-Dawley rats. Mol Cell Biochem. 2015;399(1-2):257-68.

36. Ashraf JM, Ansari MA, Khan HM, Alzohairy MA, Choi I. Green synthesis of silver nanoparticles and characterization of their inhibitory effects on AGEs formation using biophysical techniques. Sci Rep. 2016;6:20414.

37. Swanner J, Mims J, Carroll DL, Akman SA, Furdui CM, Torti SV, et al. Differential cytotoxic and radiosensitizing effects of silver nanoparticles on triple-negative breast cancer and non-triplenegative breast cells. Int J Nanomedicine. 2015;10:3937-53.

38. Fahrenholtz CD, Swanner J, Ramirez-Perez M, Singh RN. Heterogeneous Responses of Ovarian Cancer Cells to Silver Nanoparticles as a Single Agent and in Combination with Cisplatin. J Nanomater. 2017;2017.

39. Liu P, Huang Z, Chen Z, Xu R, Wu H, Zang F, et al. Silver nanoparticles: a novel radiation sensitizer for glioma? Nanoscale. 2013;5(23):11829-36. 
40. Locatelli E, Naddaka M, Uboldi C, Loudos G, Fragogeorgi E, Molinari V, et al. Targeted delivery of silver nanoparticles and alisertib: in vitro and in vivo synergistic effect against glioblastoma. Nanomedicine (Lond). 2014;9(6):839-49.

41. Miura N, Shinohara Y. Cytotoxic effect and apoptosis induction by silver nanoparticles in HeLa cells. Biochem Biophys Res Commun. 2009;390(3):733-7.

42. Kawata K, Osawa M, Okabe S. In vitro toxicity of silver nanoparticles at noncytotoxic doses to HepG2 human hepatoma cells. Environ Sci Technol. 2009;43(15):6046-51.

43. Sanpui P, Chattopadhyay A, Ghosh SS. Induction of apoptosis in cancer cells at low silver nanoparticle concentrations using chitosan nanocarrier. ACS Appl Mater Interfaces. 2011;3(2):21828.

44. Beer C, Foldbjerg R, Hayashi Y, Sutherland DS, Autrup H. Toxicity of silver nanoparticles - nanoparticle or silver ion? Toxicol Lett. 2012;208(3):286-92.

45. Zielinska E, Zauszkiewicz-Pawlak A, Wojcik M, Inkielewicz-Stepniak I. Silver nanoparticles of different sizes induce a mixed type of programmed cell death in human pancreatic ductal adenocarcinoma. Oncotarget. 2018;9(4):4675-97.

46. Guo D, Zhao Y, Zhang Y, Wang Q, Huang Z, Ding Q, et al. The cellular uptake and cytotoxic effect of silver nanoparticles on chronic myeloid leukemia cells. J Biomed Nanotechnol. 2014;10(4):669-78.

47. Guo D, Zhu L, Huang Z, Zhou H, Ge Y, Ma W, et al. Anti-leukemia activity of PVP-coated silver nanoparticles via generation of reactive oxygen species and release of silver ions. Biomaterials. 2013;34(32):7884-94.

48. Sriram MI, Kanth SB, Kalishwaralal K, Gurunathan S. Antitumor activity of silver nanoparticles in Dalton's lymphoma ascites tumor model. Int J Nanomedicine. 2010;5:753-62.

49. Orta-García ST, Plascencia-Villa G, Ochoa-Martínez AC, Ruiz-Vera T, Pérez-Vázquez FJ, VelázquezSalazar JJ, et al. Analysis of cytotoxic effects of silver nanoclusters on human peripheral blood mononuclear cells 'in vitro'. J Appl Toxicol. 2015;35(10):1189-99.

50. M JF, P L. Apoptotic efficacy of biogenic silver nanoparticles on human breast cancer MCF-7 cell lines. Prog Biomater. 2015;4(2-4):113-21.

51. Vakkala M, Pääkkö P, Soini Y. Expression of caspases 3, 6 and 8 is increased in parallel with apoptosis and histological aggressiveness of the breast lesion. Br J Cancer. 1999;81(4):592-9.

52. Mukherjee P, Ahmad A, Mandal D, Senapati S, Sainkar SR, Khan MI, et al. Fungus-Mediated Synthesis of Silver Nanoparticles and Their Immobilization in the Mycelial Matrix: A Novel Biological Approach to Nanoparticle Synthesis. Nano Letters. 2001;1(10):515-9.

53. Urbańska K, Pająk B, Orzechowski A, Sokołowska J, Grodzik M, Sawosz E, et al. The effect of silver nanoparticles (AgNPs) on proliferation and apoptosis of in ovo cultured glioblastoma multiforme (GBM) cells. Nanoscale Res Lett. 2015;10:98.

54. Inwald EC, Klinkhammer-Schalke M, Hofstädter F, Zeman F, Koller M, Gerstenhauer M, et al. Ki-67 is a prognostic parameter in breast cancer patients: results of a large population-based cohort of a 
55. Scholzen T, Gerdes J. The Ki-67 protein: from the known and the unknown. J Cell Physiol. 2000;182(3):311-22.

56. Koch A, Tamez P, Pezzuto J, Soejarto D. Evaluation of plants used for antimalarial treatment by the Maasai of Kenya. J Ethnopharmacol. 2005;101(1-3):95-9.

57. Léonce S, Pérez V, Lambel S, Peyroulan D, Tillequin F, Michel S, et al. Induction of cyclin E and inhibition of DNA synthesis by the novel acronycine derivative S23906-1 precede the irreversible arrest of tumor cells in S phase leading to apoptosis. Mol Pharmacol. 2001;60(6):1383-91.

58. Kasibhatla S, Amarante-Mendes GP, Finucane D, Brunner T, Bossy-Wetzel E, Green DR. Acridine Orange/Ethidium Bromide (AO/EB) Staining to Detect Apoptosis. CSH Protoc. 2006;2006(3).

59. Jing Y, Tong C, Zhang J, Nakamura T, lankov I, Russell SJ, et al. Tumor and vascular targeting of a novel oncolytic measles virus retargeted against the urokinase receptor. Cancer Res. 2009;69(4):1459-68.

60. El-Seedi HR, El-Shabasy RM, Khalifa SAM, Saeed A, Shah A, Shah R, et al. Metal nanoparticles fabricated by green chemistry using natural extracts: biosynthesis, mechanisms, and applications. RSC Advances. 2019;9(42):24539-59.

\section{Figures}




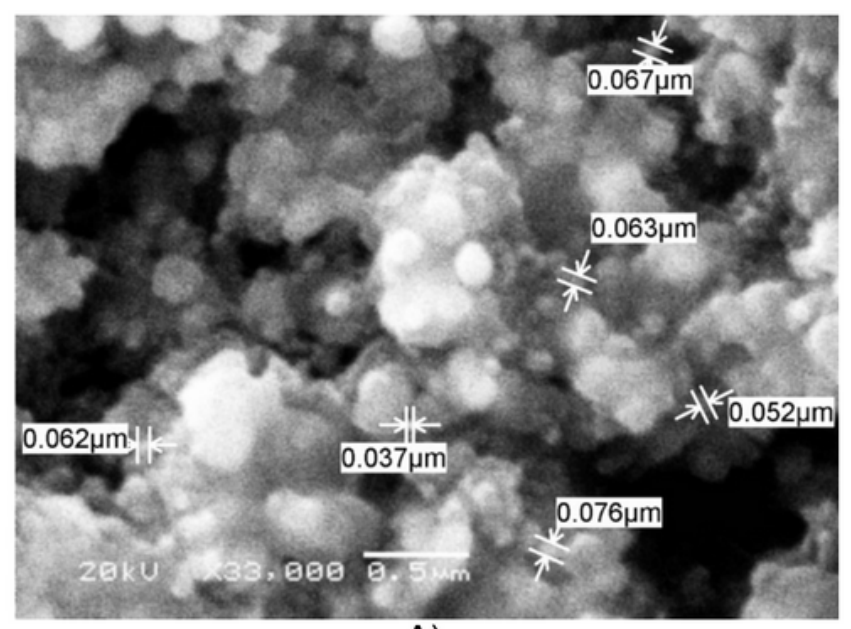

A)

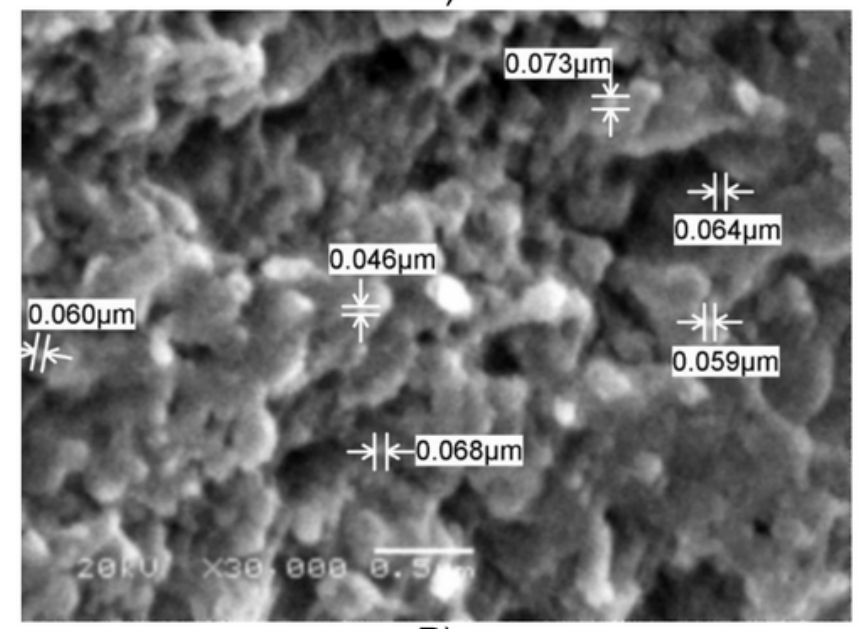

B)

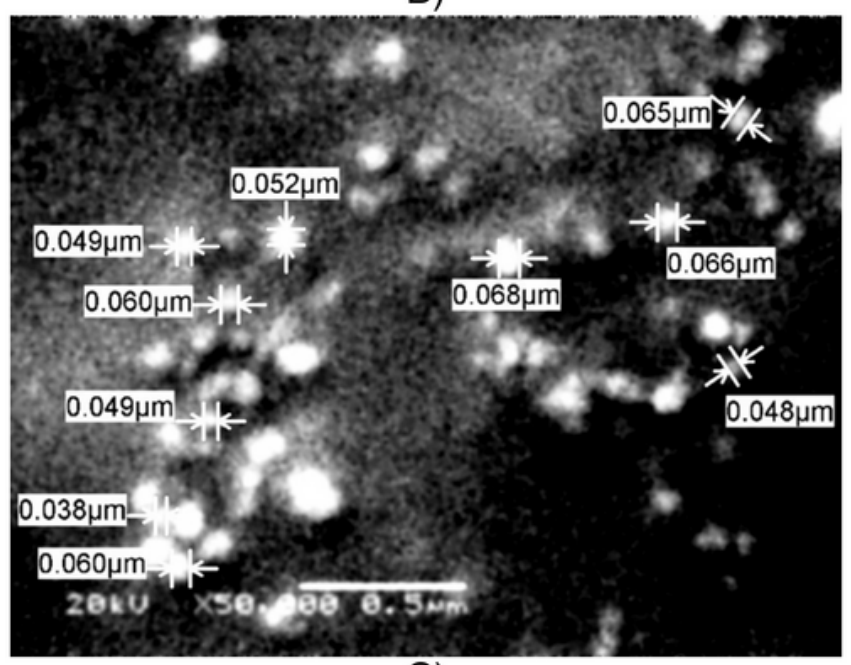

C)

\section{Figure 1}

Scanning electron microscopy image of green synthesized AgNPs. A) AgNPs biosynthesized by C. vulgaris cell free supernatant (Chlorella bio-AgNPs), B) AgNPs biosynthesized by $\mathrm{M}$. aeruginosa cell free supernatant (Microcystis bio-AgNPs) and C) AgNPs biosynthesized by Arthrospira platensis cell free supernatant (Arthrospira bio-AgNPs). 


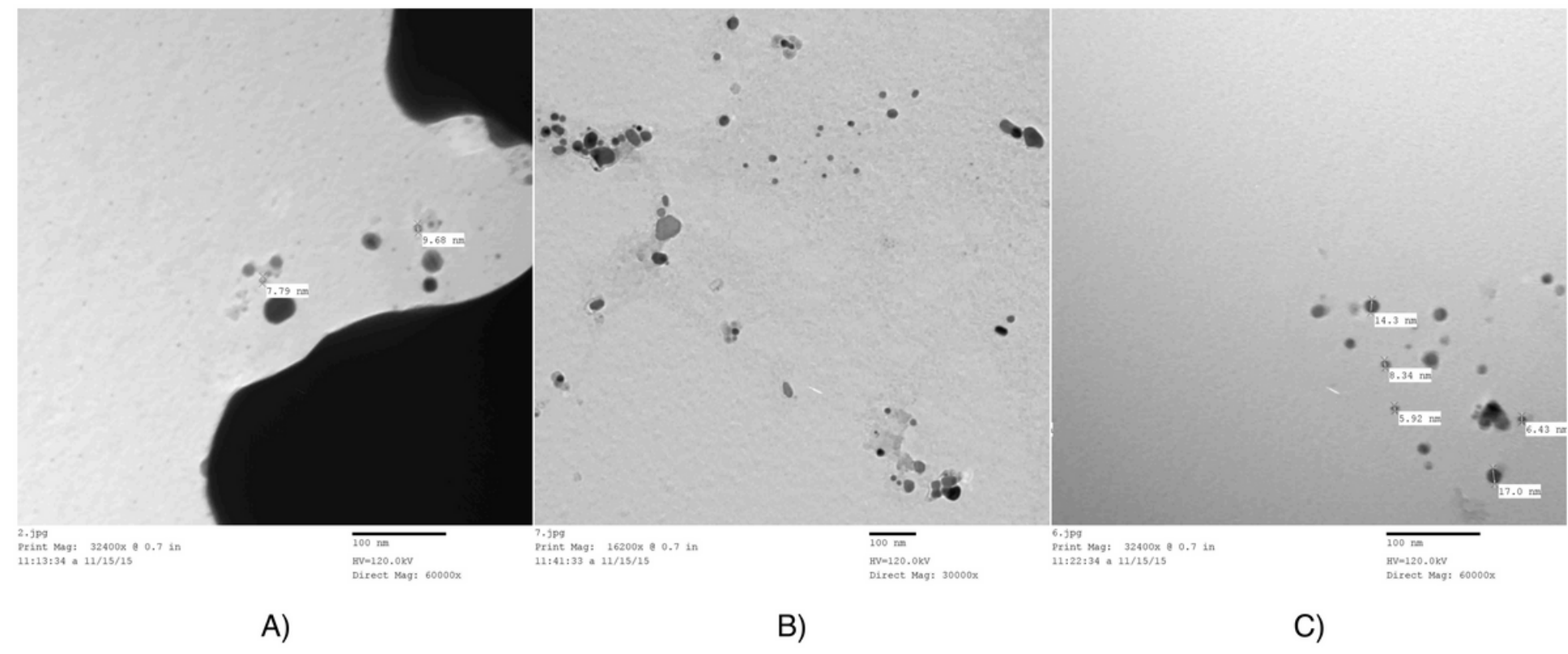

\section{Figure 2}

Transmission electron microscopy image of green synthesized AgNPs. A) AgNPs biosynthesized by C. vulgaris cell free supernatant (Chlorella bio-AgNPs), B) AgNPs biosynthesized by $\mathrm{M}$. aeruginosa cell free supernatant (Microcystis bio-AgNPs) and C) AgNPs biosynthesized by Arthrospira platensis cell free supernatant (Arthrospira bio-AgNPs). 

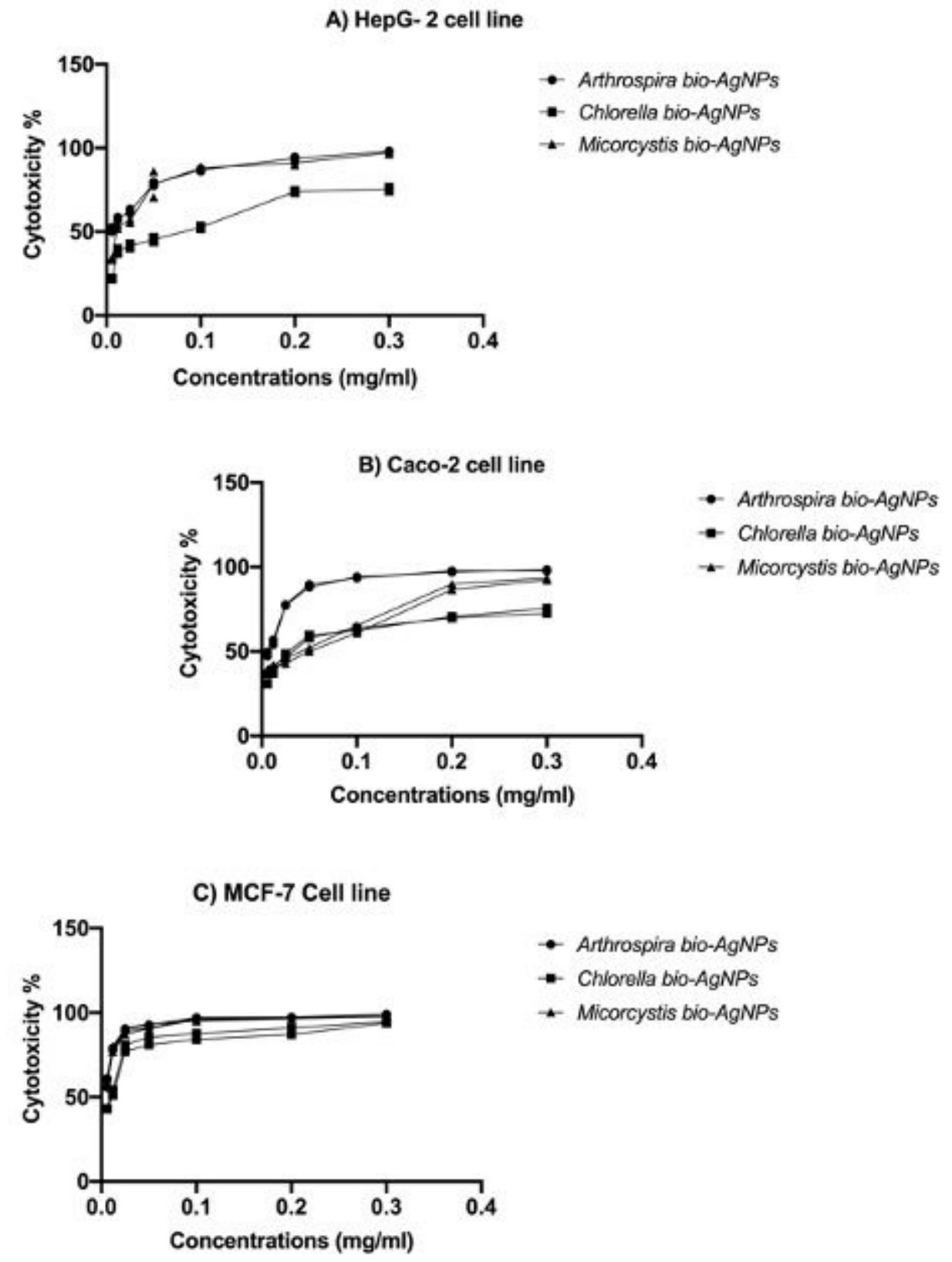

Figure 3

The Anticancer activity of the biogenic AgNPs . The anticancer activity of the Chlorella bio-AgNPs, Microcystis bio-AgNPs and Arthrospira bio-AgNPs were quantified using MTS using different treatment concentrations against: A) HepG-2 cell line, B) CaCO-2 cell line and C) MCF-7 cell line. 

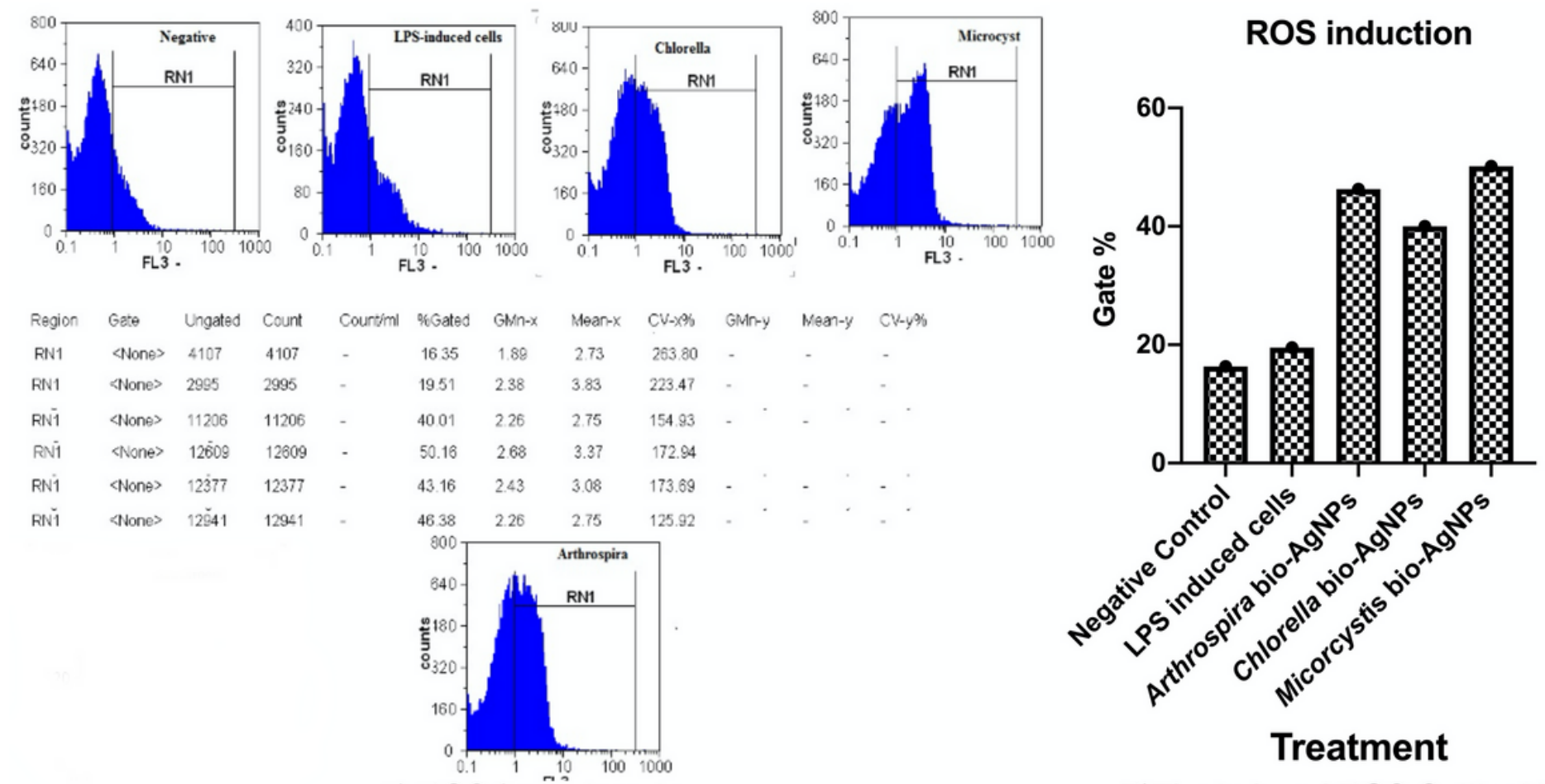

A) ROS flowcytometry

Treatment

B)The induced ROS Gatting\%

\section{Figure 4}

The intracellular reactive oxygen species induced after AgNPs treatment. The induced ROS in PBMCs inflammatory models were quantified after Chlorella bio-AgNPs, Microcystis bio-AgNPs and Arthrospira bio-AgNPs treatment using IC50 concentrations. The induced ROS were quantified using H2DCF-DA and flowcytometry, the results were expressed as Gating \% after H2DCF-DA and compared with the LPSinduced PBMCs (lipopolysaccharide $100 \mathrm{ng} / \mathrm{ml}$ ).

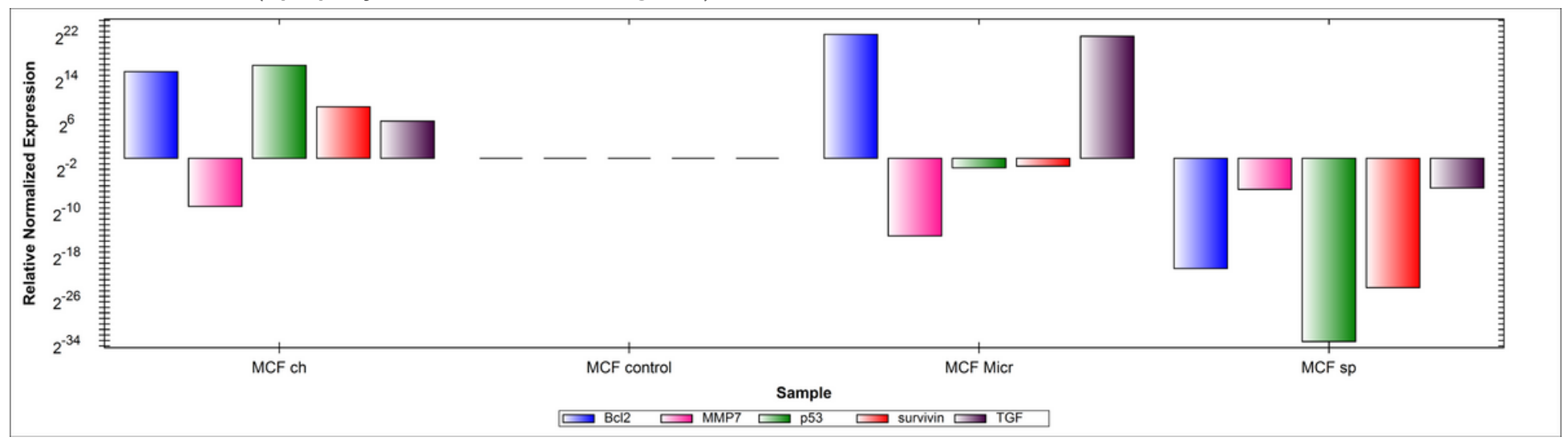

Figure 5

The regulatory effects of Arthrospira bio-AgNPs treatment on oncogenes and tumor suppressor genes. The regulatory effects of Arthrospira bio-AgNPs on p53, Bcl2, MMp7 (metalloproteinase 7), TGFa (Transforming growth factor) and Survivin genes were quantified after 24 hrs treatments with sub-IC50 concentrations using RTqPCR. 


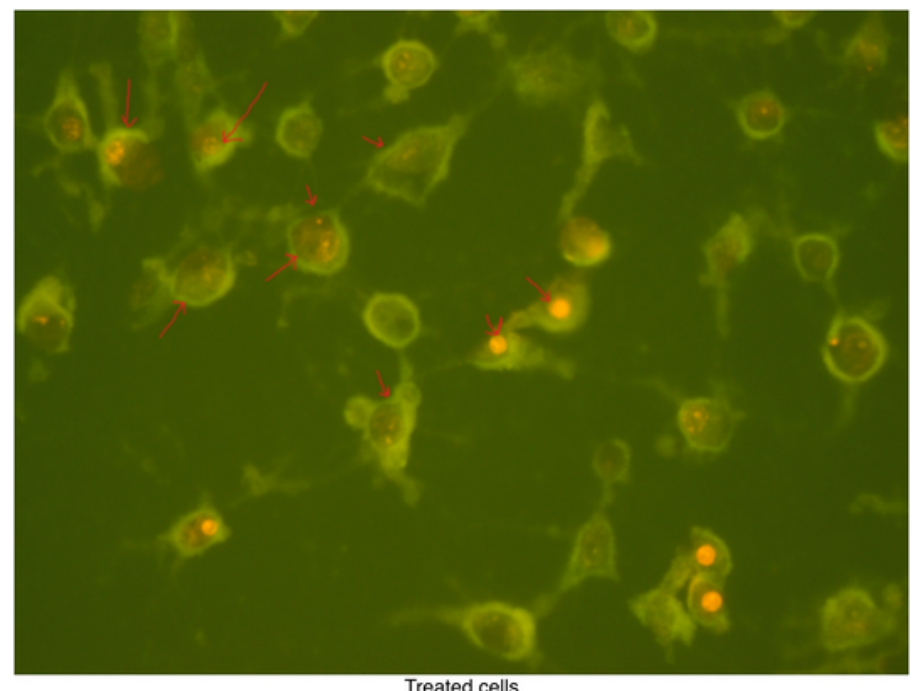

Treated cells

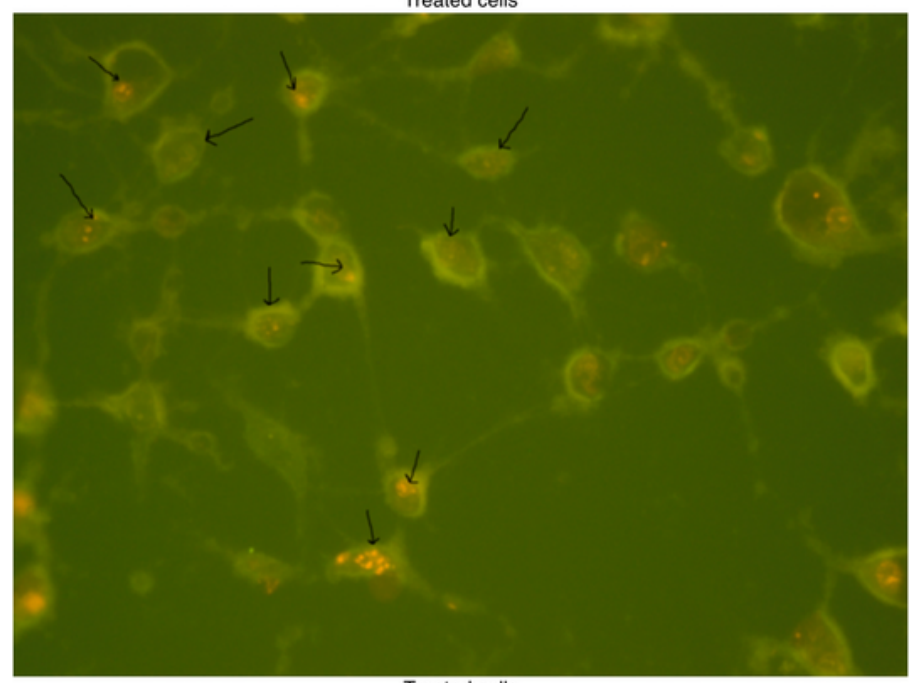

Treated cells

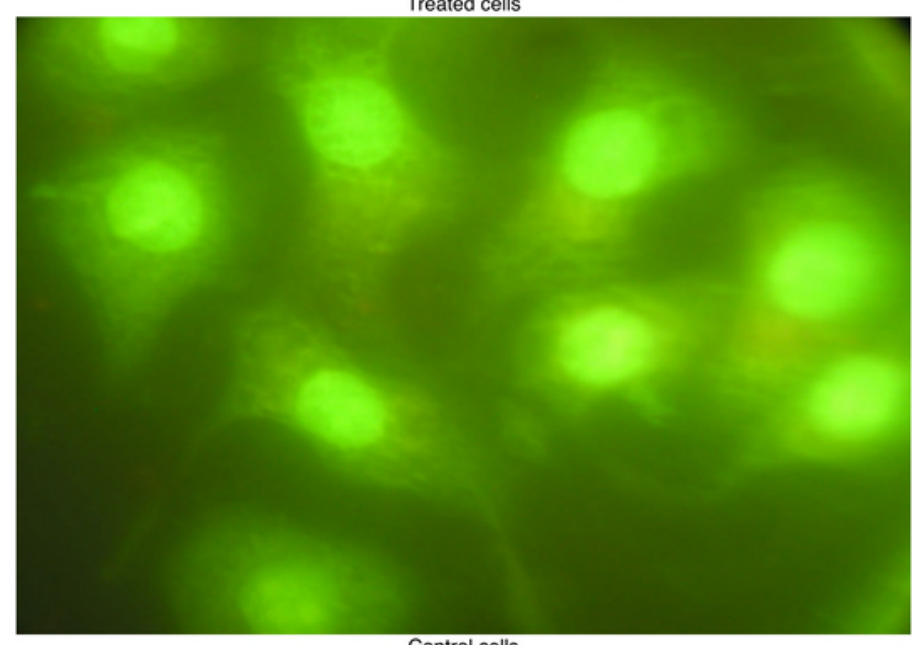

Control cells

\section{Figure 6}

Induction of apoptosis and necrosis after bio-AgNPs treatment. MCF7 cancer cells treated with Arthrospira bio-AgNPs IC50 concentration. Arrows indicate early apoptotic cells and multinucleated cells, cells with condensed nucleus and necrotic staged cells. 
A)
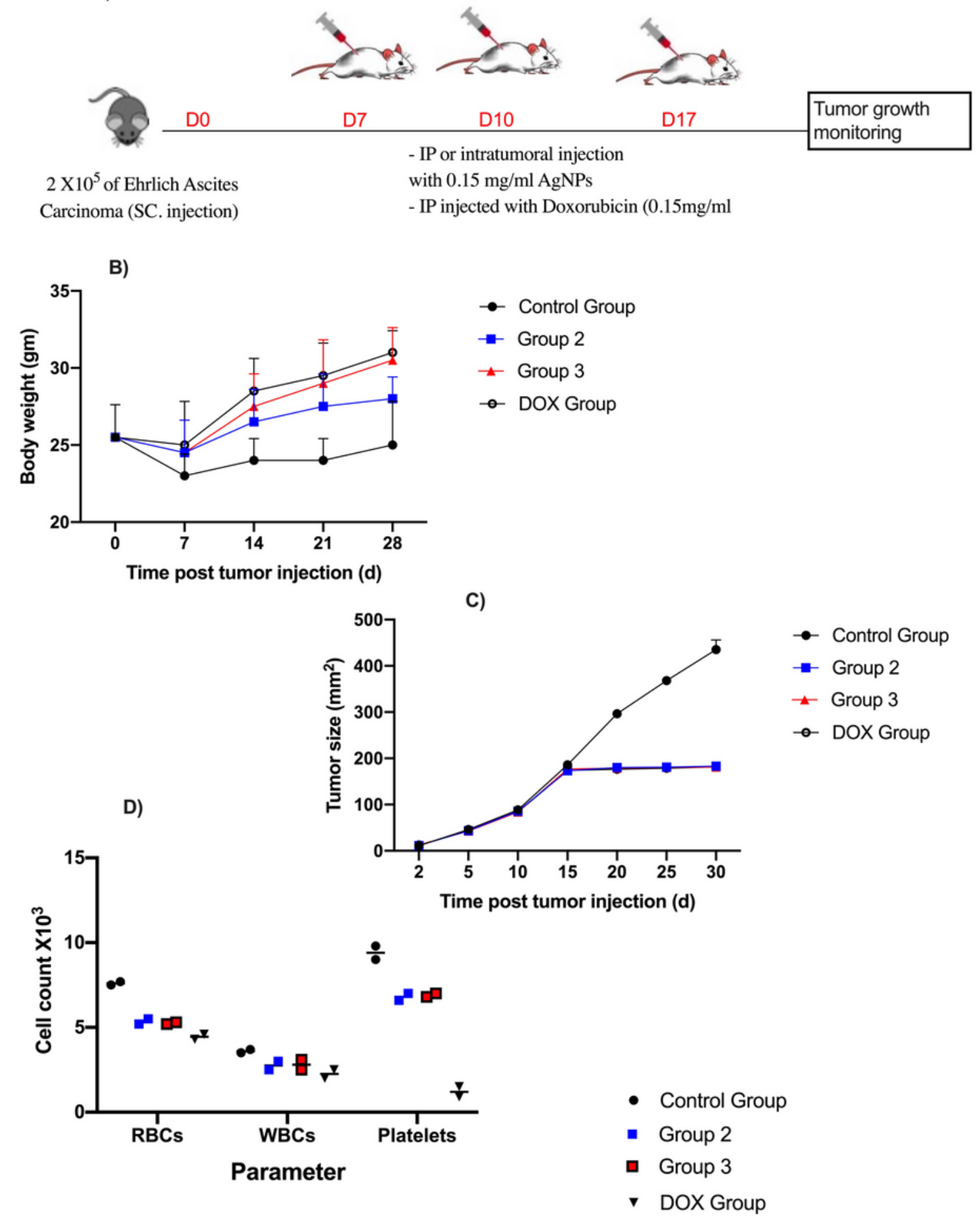

\section{Figure 7}

The control of breast cancer growth using Arthrospira bio-AgNPs in-vivo Body weight ( $A$ ) and tumor size (B) Platelets, WBCs and RBCs counts that recorded over 28 days in three groups of tumors bearing females BALB/C mice (each group have 5 mice). Group1: Negative control mice; mice were IP injected with $9 \%$ saline. Group 2: Mice were injected locally (intertumoral injections) with $0.15 \mathrm{mg} / \mathrm{ml}$ of 
Arthrospira (3.5gm/ $\mathrm{Kg}$ body weight). DOX group: mice were IP injected with Doxorubicin (DOX; $0.15 \mathrm{mg} / \mathrm{ml} ; 3.5 \mathrm{gm} / \mathrm{Kg}$ body weight).

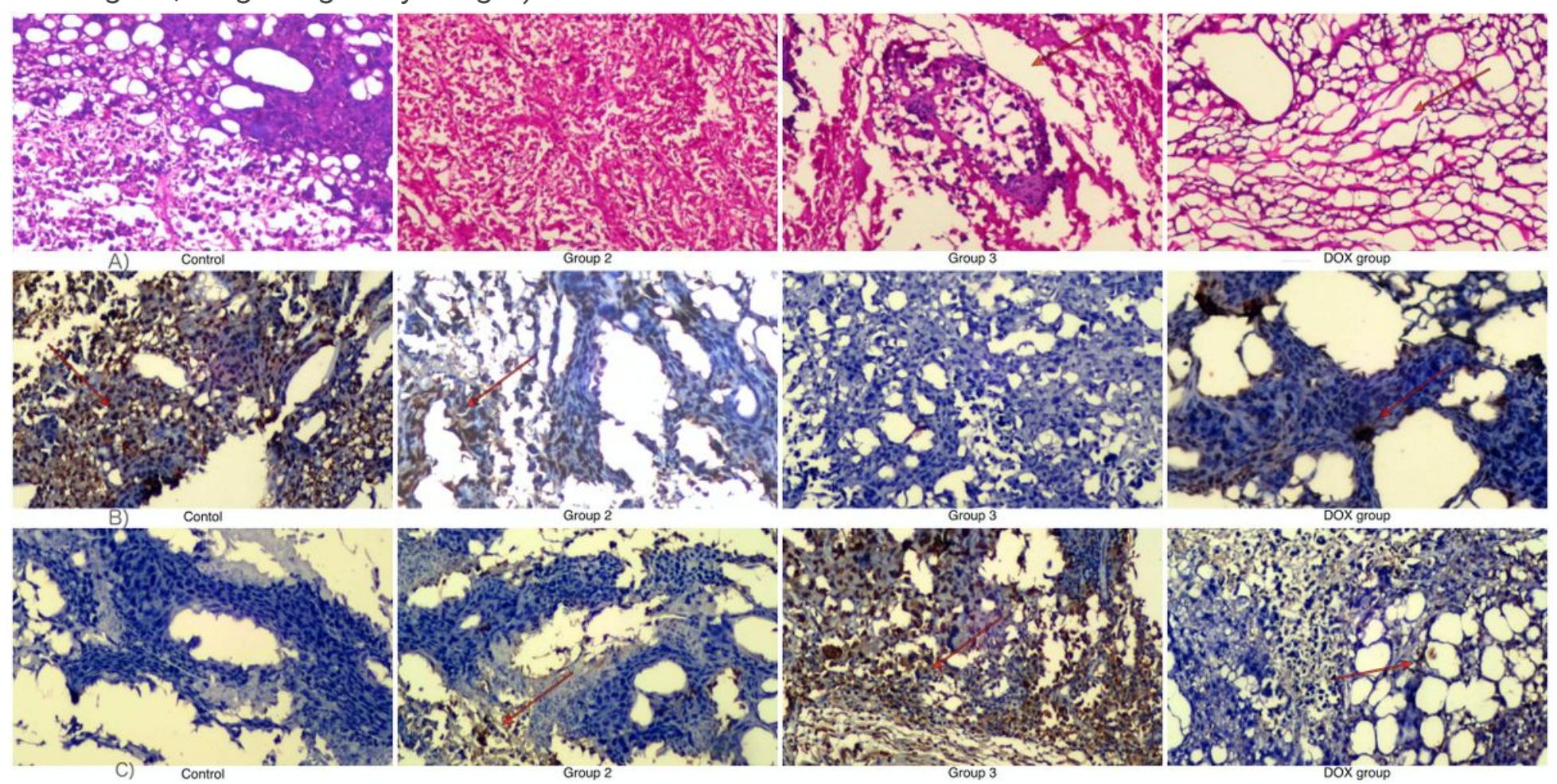

Figure 8

Histopathology and Immunohistochemistry stanning sections of breast tumor and adjacent stroma from individual The upper 4 figure showed the histopathological stanning with (H\&E), examined microscopically for presence of negative features, such as edema, erosion and necrosis. The second 4 figures in the middle showed the Immunohistochemistry staining of Ki 67 protein and the lower 4 figures represent Immunohistochemistry staining of caspase 3 protein. (a) Negative control mice; mice were IP injected with $9 \%$ saline, (b) Mice were injected locally (intertumoral injections) with $0.15 \mathrm{mg} / \mathrm{ml}$ of Arthrospira (3.5gm/ Kg body weight), (c) mice were injected intraperitonially with $0.15 \mathrm{mg} / \mathrm{ml}$ of Arthrospira (3.5gm/ Kg body weight), (d) mice were IP injected with Doxorubicin (DOX; $0.15 \mathrm{mg} / \mathrm{ml}$; $3.5 \mathrm{gm} / \mathrm{Kg}$ body weight).

\section{Supplementary Files}

This is a list of supplementary files associated with this preprint. Click to download.

- graphicalabstract.png

- Supplementaryfile.pdf 